\title{
STUDY OF NITROGEN AND PHOSPHORUS FLOW IN WATER, AQUATIC PLANTS AND SEDIMENT
}

\author{
ZHU, X. $.^{1,2}-$ CHEN, Y. P. ${ }^{1,2^{*}}-$ GAN, M. ${ }^{1,2}-$ ZHOU, J. J. ${ }^{1,2}-$ HU, X. D. ${ }^{3}$ \\ ${ }^{1}$ State Key Laboratory of Hydrology-Water Resource and Hydraulic Engineering, Hohai \\ University, 1 Xikang Road, Nanjing 210098, China \\ ${ }^{2}$ College of Harbour, Coastal and Offshore Engineering, Hohai University, 1 Xikang Road, \\ Nanjing 210098, China \\ (phone: +86-138-1390-6122; fax: +86-25-8378-7708) \\ ${ }^{3}$ Jiangsu Hydraulic Research Institute, 97 Nanhu Road, Nanjing 210017, China \\ (phone: +86-189-3600-6564; fax: +86-25-8645-5646) \\ *Corresponding author \\ e-mail:ypchen@hhu.edu.cn \\ (Received $13^{\text {th }}$ Jul 2019; accepted $25^{\text {th }}$ Nov 2019)
}

\begin{abstract}
Using aquatic plants to control nitrogen $(\mathrm{N})$ and phosphorus $(\mathrm{P})$ loads and restore eutrophic lakes has been put into practice since the 1980s. However, existing studies can hardly illustrate the law of N\&P flow in water, aquatic plants and sediment during the growth of plants. In this study, three typical aquatic plants, two emerged plants and one submerged plant from Lake Gehu, China, were chosen to study the rule of N\&P flow. The N\&P contents and some related parameters in the water, sediment and plant samples were measured and the correlations between them were analyzed. The results show that the flow of N\&P is generally controlled by the growth of plants, and $\mathrm{N}$ can flow directly between plants and sediment while $\mathrm{P}$ transfer is more significant in water and sediment. In emerged plants, $70-75 \%$ total nitrogen (TN) and over 50\% total phosphorus (TP) is concentrated in leaves at early and medium stages of growth, and at the decline stage N\&P transfer to roots. Results also show that reaping plants around August and purifying sediment after plants decay can make nutrient removal efficiency.
\end{abstract}

Keywords: eutrophication, lakes restoration, nutrient removal, Lake Gehu, experimental study

\section{Introduction}

Eutrophication has been a worldwide water pollution problem for decades. In the lower reaches of the Yangtze River basin, China, eutrophication has been affecting people's daily life. For example, algal bloom occured in Lake Taihu around the end of May and lasted for 2 months in 2007. It affected the nearby city Wuxi where more than 2 million people were short of drinking water (Guo, 2007). From 2011 to 2013, cyanobacteria have comprised over $99 \%$ of total phytoplankton biomass in Lake Chaohu during the whole summer which affected water supply for 7.6 million people (Zhang et al., 2015). Although the Chinese government has taken actions to restore the aquatic ecosystem, the annual surveys of water quality of lakes, from 2006 to 2016, show a high proportion of eutrophicated lakes at around $78 \%$. In short, eutrophication is still a serious problem in China.

For a long time, phosphorus $(\mathrm{P})$ has been considered as the elemental factor to stimulate excess growth of phytoplankton and further trigger algae bloom (Hilton et al., 2006). However, some experiment results show that only controlling $P$ loads does not have a significant effect on eutrophic status. Meanwhile, nitrogen $(\mathrm{N})$ was discovered as another essential factor that contributes to eutrophication process (Dodds, 2007). Also, it 
is now commonly accepted that reducing both N\&P loads can reduce water nutrient level (Conley et al., 2009).

Using aquatic plants to control N\&P loads and restore eutrophic lakes is widely recognized in ecology (Qiu et al., 2001; Xiao et al., 2009) since aquatic plants can absorb and assimilate nutrients, and also stimulate the microbial action of the rhizosphere (Hans, 1997). There are many studies on aquatic plants in eutrophic environment. Periphyton and phytoplankton together with macrophyte are indicators of a eutrophic environment (Hilton et al., 2006). Furthermore, the coexistence of snails and submerged plants can decrease concentrations of N\&P in water (Mo et al., 2017), but various species of plants have different abilities of removing excess nutrients (Wen and Recknagel, 2002). However, aquatic plants growing environment is complex, it also contains water and sediment, which both have impact on nutrient loads. For example, physical and chemical properties of water can make enormous difference, like calcium phosphate (Ca-P) dissolved very easily at low $\mathrm{pH}$ while aluminium phosphate (Al-P) dissolved more easily at high $\mathrm{pH}$ (Smil, 2000); ferric ion $\left(\mathrm{Fe}^{3+}\right)$ will reduce to ferrous ion $\left(\mathrm{Fe}^{2+}\right)$ when water is anaerobic which can cause ferric phosphate (Fe-P) to dissolve (Liu et al., 2002). Hydraulic dynamics is also a significant factor of nutrient transfer, like the retention time of water (O'Hare et al., 2018) and flow velocity (Hilton et al., 2006). Besides, adsorption and desorption of sediment have essential effects in transferring N\&P (Wang et al., 2018; Meghdadi, 2018) since mineral composition and some other sediment characteristics play key roles in this process (Smil, 2000). As indicated above, existing studies make good explanations on factors affecting $\mathrm{N} \& \mathrm{P}$ transferring, but lack showing the process of $\mathrm{N} \& \mathrm{P}$ flow in the whole aquatic environment system.

Although lake ecological restoration is carried out by cultivating aquatic plants, surveys revealed that the lake eutrophication in China hadn't been alleviated significantly in recent years (China water resources bulletin 2010-2016). The result does not meet expectations due to the lack of scientific management, which further indicates the importance of learning the rule of $\mathrm{N} \& \mathrm{P}$ flowing between water, aquatic plants and sediment. This will therefore serve as a guide to form a rational and systematic management of aquatic plants for effective restoration of eutrophic lakes. Furthermore, diversity of aquatic plants varies a lot with time and space (Rooney et al., 2011; Bolpagni et al., 2018). Such perspective can be reflected in Lake Gehu. From 1970 to 2007, the total aquatic plants coverage had a sharp decline (Xu et al., 2013). Since 2012, several types of emerged plants were cultivated in shallow areas (Wu et al., 2017). This means surveys of aquatic plants species should be conducted before learning the rule of N\&P flowing in water, aquatic plants and sediment.

Hence, the present work has been undertaken with the following objectives: (1) Figuring out the changing processes of N\&P concentration in water, aquatic plants and sediment during aquatic plants growth, respectively. (2) Learning the rule of N\&P flowing in water-aquatic plants-sediment within a life cycle of aquatic plants. (3) Giving suggestions on using aquatic plants to restore eutrophic lakes.

\section{Materials and Methods}

\section{Study area}

This study is based on the background of Lake Gehu, China. The coordinates of the lake are $119^{\circ} 44^{\prime} \mathrm{E}-119^{\circ} 52^{\prime} \mathrm{E}$ and $31^{\circ} 28^{\prime} \mathrm{N}-31^{\circ} 44^{\prime} \mathrm{N}$ (Fig. 1). Lake Gehu, the main source of drinking water for nearby residents, is an important shallow lake in the south of Lake 
Taihu in Jiangsu province, China (Fig. 1a), which belongs to the Taihu basin. It is a typical shallow aquatic vegetation lake. The water storage area is $144.1 \mathrm{~km}^{2}$ and the average water depth is $1.31 \mathrm{~m}$. The lake has a moderate and humid climate and also has sufficient sunlight. And the annual mean temperature is around $16.7^{\circ} \mathrm{C}$. It plays an essential role in protecting the water quality of Lake Taihu, forming the most important natural defense line for Lake Taihu (Xu et al., 2013). Around 16 rivers enter into it from west, while 15 others divert from south-east (Fig. 1b). Lake Gehu has been eutrophic for over a decade with a strong adverse influence on local freshwater supply, and aquaculture. Since 2009, the local government carried out many measures to restore Lake Gehu including aquatic plant restoration (Wu et al., 2017). However, the algal bloom still occurs in high frequency, especially in summer.
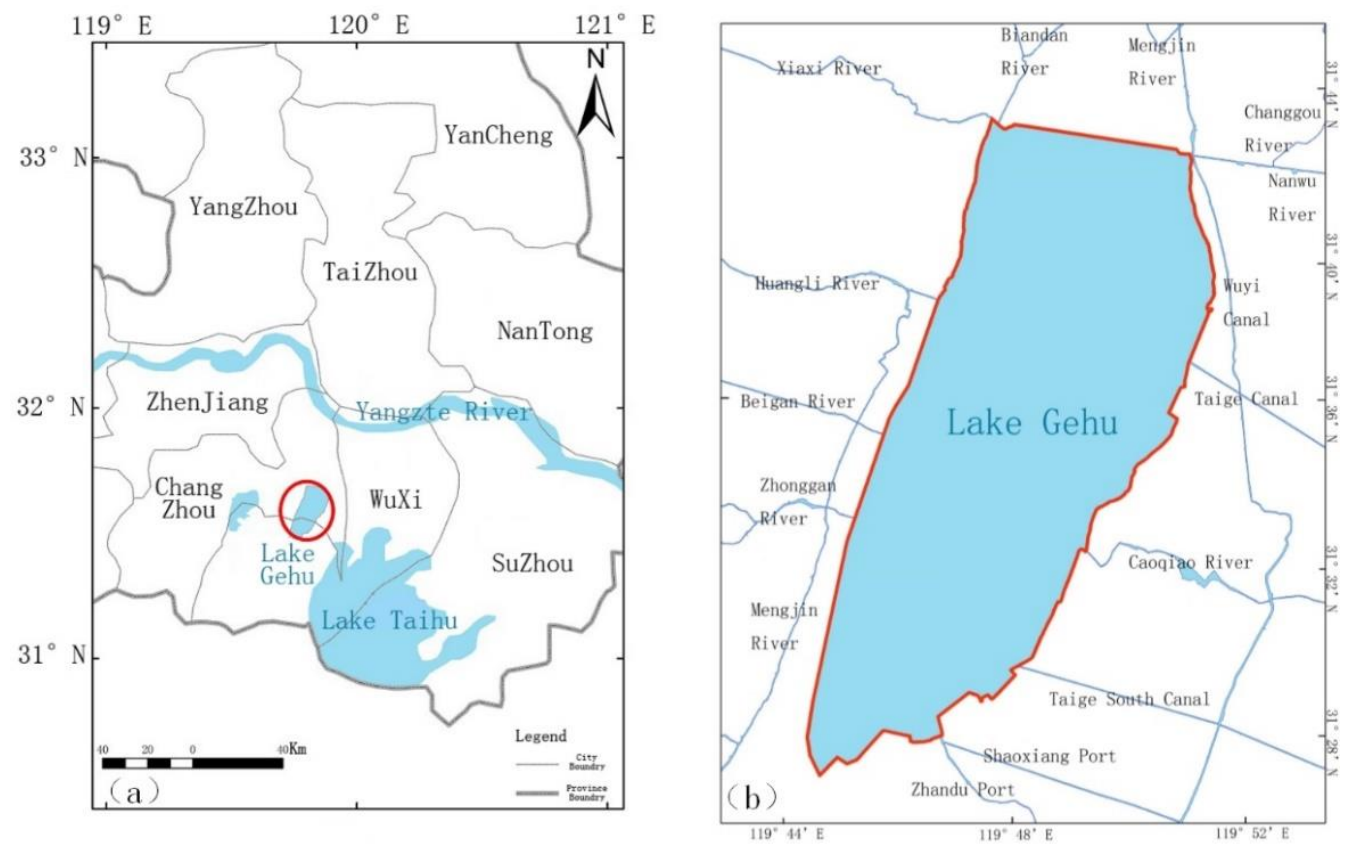

Figure 1. Location (a) and River system (b) of Lake Gehu

\section{Experiment materials}

Materials for experiments and relative value settings are based on the results of a field investigation, which are shown in the results section.

Aquatic plants: Two emerged plants Phragmites australis (Ph.a.), Zizania latifolia (Z.l.), and one submerged plant Hydrilla verticillata (H.v.) were collected at the same time from Lake Gehu, in the early of April when plants were at their initial stage of growth, for indoor cultivating experiment particularly.

Water: $\mathrm{NH}_{4} \mathrm{Cl}$ and $\mathrm{KH}_{2} \mathrm{PO}_{4}$ were used to formulate experimental water. Initial $\mathrm{N} \& \mathrm{P}$ concentration were set at $2.0 \mathrm{mg} / \mathrm{L}$ and $0.2 \mathrm{mg} / \mathrm{L}$, respectively.

Sediment: Experimental sediments were from areas around aquatic plants in Lake Gehu, to replicate the original growing environment for aquatic plants.

\section{Indoor experiment}

The indoor cultivating experiments were conducted in $70 \mathrm{~L}(0.5 * 0.35 * 0.4 \mathrm{~m})$ cubic plastic containers. In each container, there were about $50 \mathrm{~L}$ water with initial N\&P 
concentration, moderate sediment at bottom (around $0.12 \mathrm{~m}$ depth), and $500 \mathrm{~g}$ submerged plants or 5 emerged plants. The total water depth was around $0.3 \mathrm{~m}$. Besides, control experiments (no plants) were also arranged. Each container had a duplicate (Fig. 2). All containers were settled together to ensure other environmental conditions unified. The experiment was conducted in a ventilated indoor area. The temperature was set at room temperature. The avarage temperture was around $20^{\circ} \mathrm{C}$ while it reached $7-8^{\circ} \mathrm{C}$ in December and was over $30^{\circ} \mathrm{C}$ in July and August. The sunny weather contained $60 \%$ of experimental days, thus the sunlight was abundant. The initial $\mathrm{pH}$ and the dissovled oxgen content (DO) of the water were around 6.7 and $9 \mathrm{mg} / \mathrm{L}$, repectively.
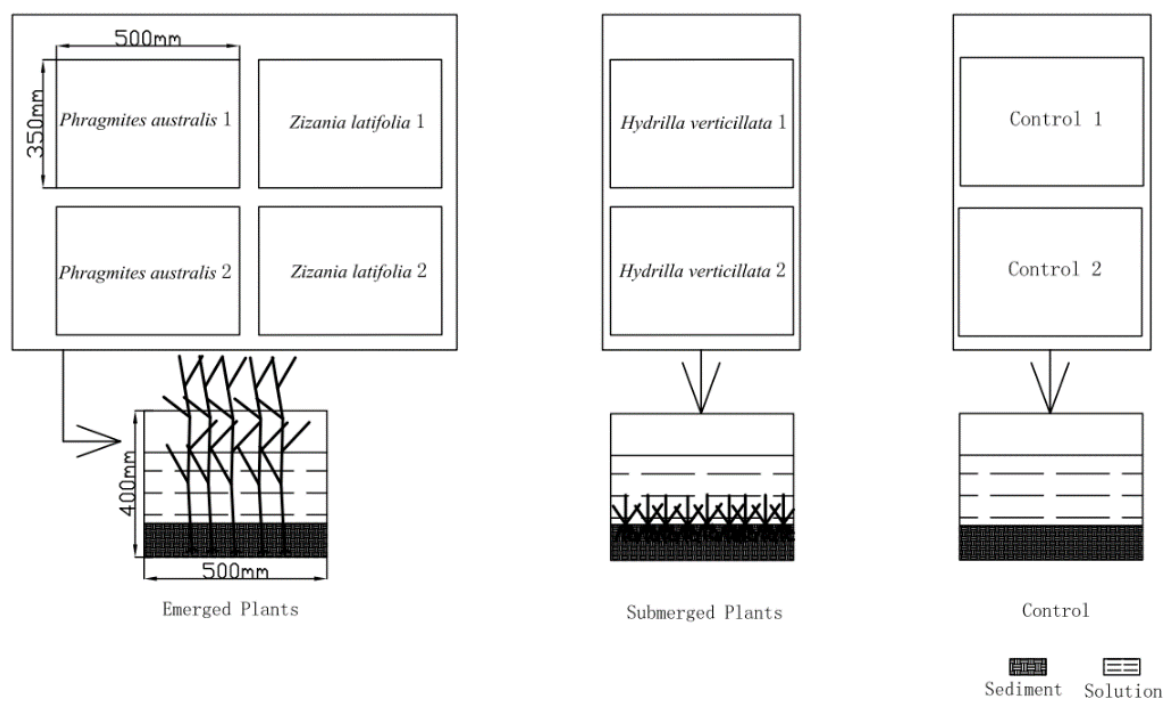

Figure 2. Experiment arrangement. Phragmites australis and Zizania latifolia are emerged plants showed in the left, Hydrilla verticillata is the submerged plant showed in the middle and control groups with no plants are showed in the right. Each experimental container has a duplicate

\section{Sampling and analysis}

The indoor cultivating experiment initiated from May and ended at the end of December 2016, covering a life cycle of aquatic plants. The frequency of taking plants and sediment samples was twice per month, around the 10th and the 20th of each month. Around $10 \mathrm{~g}$ plants samples and $50 \mathrm{~g}$ sediment samples were taken synchronously from every container every time. Emerged plant samples were separated into leaves, stems and roots, while submerged plant samples were analyzed as a whole since they were too small to separate. Samples were operated orderly by freeze-drying, grinding and sieving. Then total nitrogen concentration (TN) and total phosphorus concentration (TP) of samples were analyzed in a timely manner. TN of samples were analyzed by persulfate digestion (Smarta et al., 1983) while TP of samples were analyzed by SEDEX method (Ruttenberg, 1992). Analysis experiments of all parameters at different time were repeated 3 times. Around $200 \mathrm{ml}$ water samples were taken from each container once a week. Samples were saved in fridge with the temperature around $5^{\circ} \mathrm{C}$. Analysis experiments were conducted within $24 \mathrm{~h}$ after sampling. The following water parameters were analyzed: $\mathrm{pH}$, dissolved oxygen content (DO), chemical oxygen demand (COD), TN, TP, ammonia nitrogen $\left(\mathrm{NH}_{4}{ }^{+}-\mathrm{N}\right)$ and nitrate nitrogen $\left(\mathrm{NO}_{3}{ }^{-}-\mathrm{N}\right) \cdot \mathrm{pH}$ and $\mathrm{DO}$ were recorded by a multi-parameter 
data logger (YSI 6820). Analysis experiments of other parameters were proceeded accroding to standard techniques (APHA, 1980; Valderrama, 1981; Jin and Tu, 1990). Analysis experiments of all parameters at different times were repeated 3 times.

\section{Statistical analysis}

First, parameters of water, aquatic plants and sediment samples were sorted by time, plant species and organs. Prior to statistical analysis, the normality of data sets was tested with Shapiro-Wilk test (Wang et al., 2012). Then, the T test was applied for statistical comparison of measured values among different times, plant species and organs for judge whether a detected trend was statistically significant or not. Last, parameters of water, aquatic plants and sediment samples were analyzed by Spearman correlation analysis (IBM statistic, version 22) to learn the flow progress of $\mathrm{N} \& \mathrm{P}$ in water-aquatic plantssediment. A p-value of $<0.05$ was considered statistically significant.

\section{Result}

To obtain up-to-date distribution of aquatic plants and N\&P loads in Lake Gehu, surveys were conducted in 2016. There are about 15 species of aquatic plants: 3 submerged macrophyte, 7 emerged plants, 3 floating plants and 2 floating-leaved macrophyte. Among these species, two emerged plants Phragmites australis (Ph.a.), Zizania latifolia (Z.l.), and one submerged plant Hydrilla verticillata (H.v.), have evidently high coverage, frequency and abundance which are critical parameters to calculate the Simpson index (Magurran, 1988). TN in water was $2.343 \mathrm{mg} / \mathrm{L}$ while TP was $0.245 \mathrm{mg} / \mathrm{L}$. Both TN\&TP reach the $\mathrm{V}$ level $(\mathrm{TN}=2.0 \mathrm{mg} / \mathrm{L} ; \mathrm{TP}=0.2 \mathrm{mg} / \mathrm{L}$ ) according to the Chinese environment quality standard (Environment quality standard for surface water-GB 3838-2002) which indicates that Lake Gehu is still highly eutrophicated.

\section{$N$ and $P$ in plants}

In the experiment, May, August and December repersent the germination, flourish growth and decay periods of aquatic plants. Values of TN\&TP in plants in August are significantly higher than in May and December $(\mathrm{p}<0.05)$; There is a significant difference between emerged plants and submerged plants $(\mathrm{p}<0.05)$. A significant difference is also found between different organs of emerged plants $(\mathrm{p}<0.05)$. Changing trends of TN\&TP in plants with time, organs and species are shown in Figures 3 and 4 in detail.

Curves of TN\&TP in two emergent plant leaves are unimodal in general, while peaks mainly lie between July and September (Fig. 3). No significant difference is observed for $\mathrm{TN}$ between two emerged plant leaves $(\mathrm{p}=0.258)$. The variation range starts from around $10 \mathrm{mg} / \mathrm{g}$, gradually increases and reaches the maximum at $25 \mathrm{mg} / \mathrm{g}$, and finally decreases to about $1 \mathrm{mg} / \mathrm{g}$. TP of two emerged plants have similar start and end values, around 1.3 $\mathrm{mg} / \mathrm{g}$ and $0.1 \mathrm{mg} / \mathrm{g}$, respectively. However, the TP peak of $P$ h.a. reaches $2.5 \mathrm{mg} / \mathrm{g}$ while that of Z.l. is relatively lower at $1.8 \mathrm{mg} / \mathrm{g}$. From May to October, leaves contained the most nutrient, with TP accounting for over $50 \%$ of total and TN accounting for nearly 70$75 \%$. Values in leaves are significantly higher than in stems and roots $(\mathrm{p}<0.05)$. TN\&TP in emerged plant stems both show a continuous downward trend with fluctuation, but value ranges are significantly different $(\mathrm{p}<0.05)$. In April and May, when peaks appeared, $\mathrm{TN}$ is around $10 \mathrm{mg} / \mathrm{g}$ while $\mathrm{TP}$ is around $1.5-1.8 \mathrm{mg} / \mathrm{g}$. TN\&TP then decrease to 1.0 
$\mathrm{mg} / \mathrm{g}$ and $0.1 \mathrm{mg} / \mathrm{g}$ respectively at the end of experiment. Besides, in this two periods, TN\&TP in stems and leaves are close (TN: $p=0.637$; TP: $p=0.542$ ). TN\&TP in emerged plant roots are generally steady but fluctuate near the end of the experiment. TN\&TP in Ph.a. roots are higher than those in Z.l., although the difference is not significant (TN: $\mathrm{p}=0.071$; TP: $\mathrm{p}=0.062$ ). During May-September, TN\&TP in roots account for less than $10 \%$ of total. However, in October-December, TP in roots is significantly higher than in stems and leaves $(\mathrm{p}<0.05)$, the proportion increase with over $50 \%$. Changes of TN\&TP in emerged plant leaves, stems and roots indicate that leaves absorb large amount of nutrient and act as the main organ to store nutrient at early and medium stages of plant growth. However, when plants decay, nutrient in roots increases while that in leaves and stems both decreases. Therefore, roots are the main organ to store nutrient when emerged plants decay. In conclusion, in emerged plants, nutrients are absorbed from outside and stored mainly in leaves at early and medium stages of growth but gradually transferred to roots when decay.
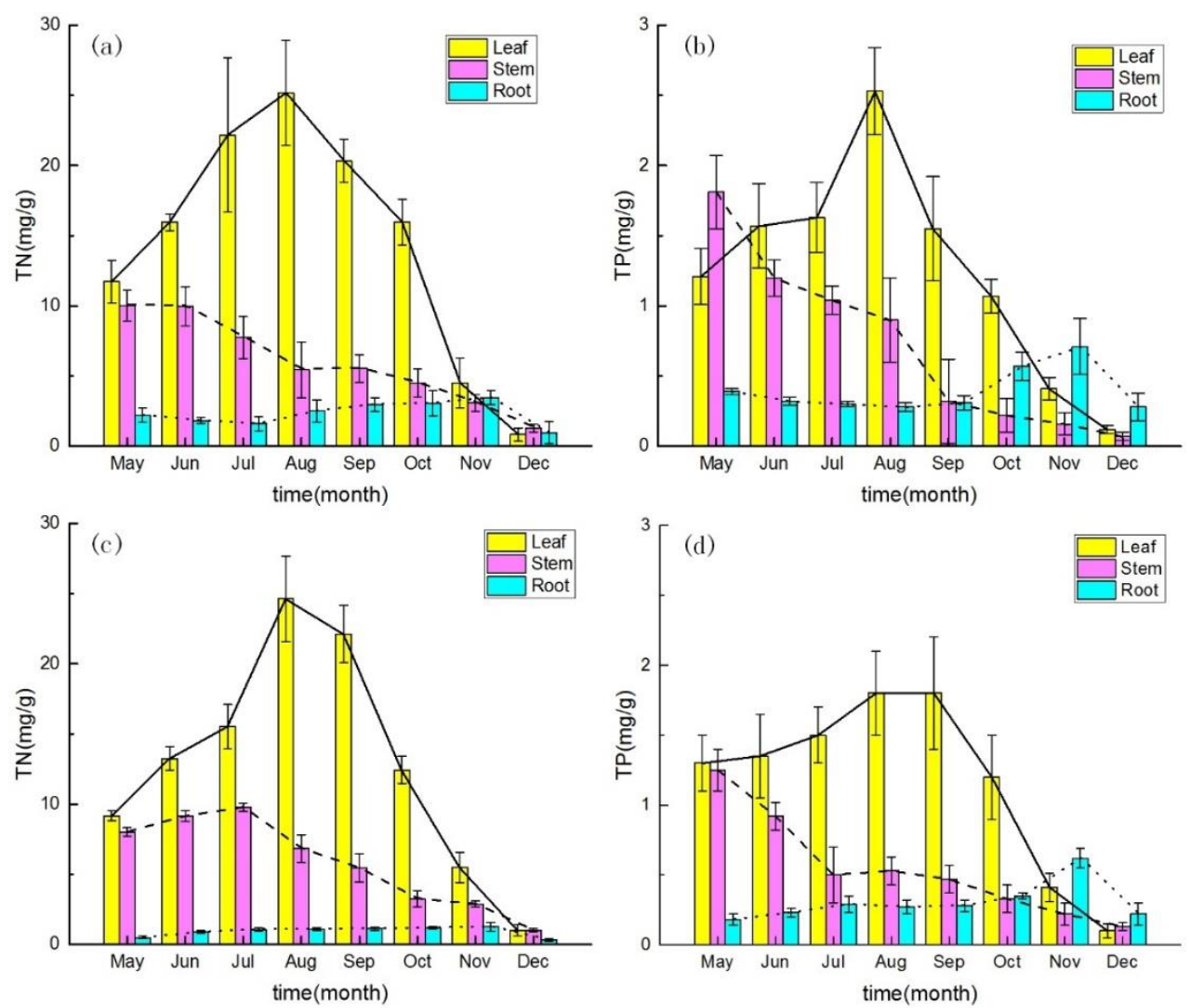

Figure 3. Total nitrogen (TN) in Phragmites australis (Ph.a.) (a), Zizania latifolia (Z.l.) (b) and total phosphorus (TP) in Ph.a.(c), Z.l.(d). In total 4 samples are collected for each month, of which 2 samples are collected at the 10th of the month and the other 2 collected at the 20th of the month. The mean values for each month are presented by color bars and the standard deviations are presented by error bars

Although curves of TN\&TP in H.v. are both unimodal (Fig. 4), values of TN are significantly higher than TP $(\mathrm{p}<0.05)$. TN increases from around $15 \mathrm{mg} / \mathrm{g}$ to around $36 \mathrm{mg} / \mathrm{g}$, then decreases to around $5 \mathrm{mg} / \mathrm{g}$. While TP increases from around $3 \mathrm{mg} / \mathrm{g}$ to about $6 \mathrm{mg} / \mathrm{g}$, then decreases to less than $1 \mathrm{mg} / \mathrm{g}$. Peaks appear in July and August. The 
ratio of TN to TP of H.v. is around 5:1 to 7:1, and this ratio of Ph.a. and Z.l. is the most around 15:1. It indicates that the growing of H.v. is limited by $\mathrm{N}$ while the growing of Ph.a. and Z.l. is limited both by $\mathrm{N}$ and $\mathrm{P}$ (Tessier et al., 2003).

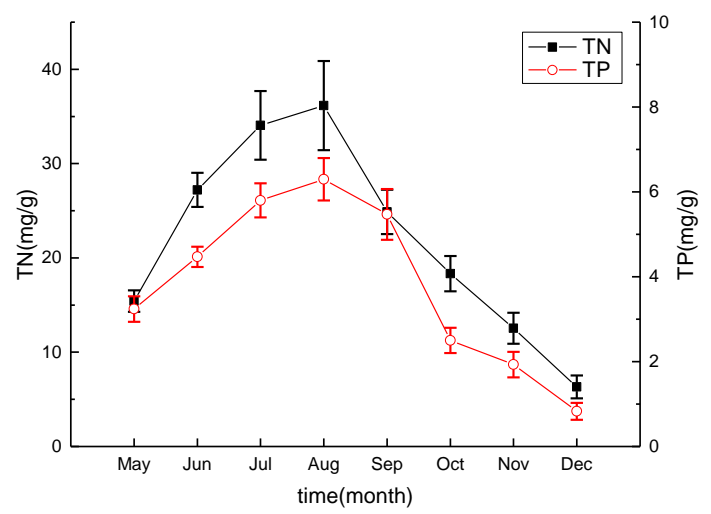

Figure 4. Total nitrogen (TN) and total phosphorus (TP) in Hydrilla verticillata (H.v.). In total 4 samples are collected for each month, of which 2 samples are collected at the 10th of the month and the other 2 collected at the 20th of the month. The standard deviations are presented by error bars

\section{$N$ and $P$ in sediment}

Values of TN\&TP in sediments in May and December are significantly higher than in August ( $p<0.05)$. There is a significant difference between control groups (no plants) and plant groups $(\mathrm{p}<0.05)$. Changing trends of TN\&TP in sediments with time are shown in Figure 5 in detail.
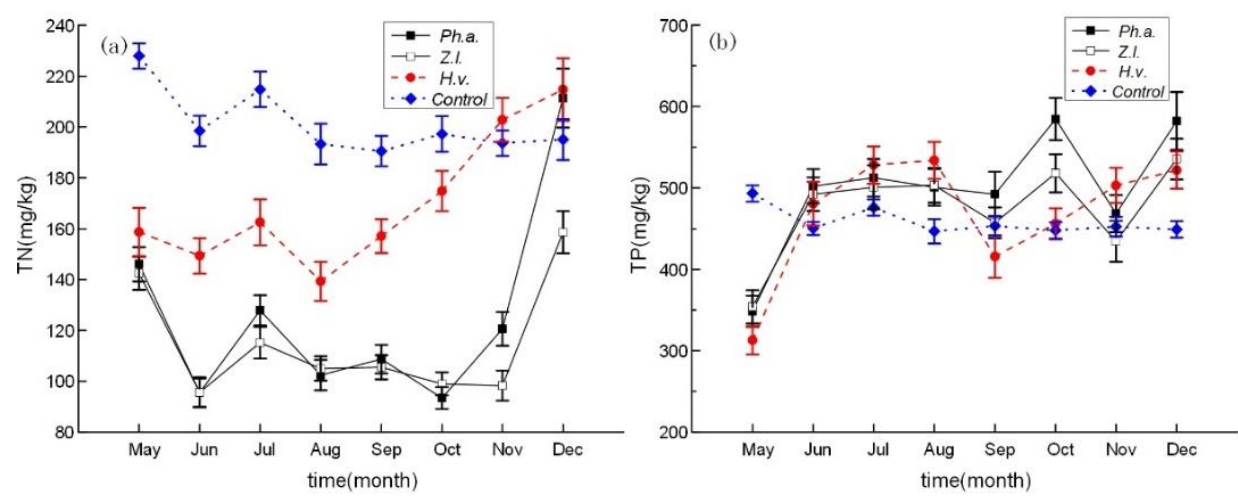

Figure 5. Changing trends of total nitrogen (TN) (a) and total phosphorus (TP) $(b)$ in sediment with time. 'Ph.a.', 'Z.l.' and 'H.v.' represent sediment samples from Phragmites australis groups, Zizania latifolia groups and Hydrilla verticillata groups, respectively. In total 4 samples are collected for each month, of which 2 samples are collected at the 10th of the month and the other 2 collected at the 20th of the month. The standard deviations are presented by error bars

No significant difference is observed for the TN\&TP in control groups sediment among different times (TN: $\mathrm{p}=0.061 ; \mathrm{TP}: \mathrm{p}=0.057$ ), changing trends are basically in stable state with slight fluctuations (Fig. 5). TN ranged from 190.54 to $227.93 \mathrm{mg} / \mathrm{kg}$, 
while TP ranged from 446.72 to $453.27 \mathrm{mg} / \mathrm{kg}$. TP decreased at the beginning because the concentration between water and sediment tended to equilibrate phosphorus concentration $\left(\mathrm{EPC}_{0}\right)$ (Zhou et al., 2005). Slight fluctuations might be caused by temperature variation. Changing trends of $\mathrm{TN}$ in the sediment of the container with emerged plants are similar (Fig. 5a). And variation ranges are close $(\mathrm{p}=0.457)$, $93.43-211.35 \mathrm{mg} / \mathrm{kg}$. In the first two months, the value sharply decreased by $50.45 \mathrm{mg} / \mathrm{kg}$ $(\mathrm{p}<0.05)$, while in the last two months, it dramatically increased by $90.72 \mathrm{mg} / \mathrm{kg}(\mathrm{p}<0.05)$. However, it was relatively stable around $93-125 \mathrm{mg} / \mathrm{kg}$ during other months. It indicates adsorption and desorption effects of sediments are not obvious when aquatic plants exist in the system. Changing trends of TP in three aquatic plants sediment are similar, rising first and then fluctuating (Fig. 5b). The value range is close ( $>>0.05)$. The minimum at the beginning was around $350.00 \mathrm{mg} / \mathrm{kg}$, then the value increased by around $150.00 \mathrm{mg} / \mathrm{kg}$ during the first month. The maximum value appeared in the end, around $550 \mathrm{mg} / \mathrm{kg}$.

\section{Water parameters}

All water parameters, except $\mathrm{NH}_{4}{ }^{+}-\mathrm{N}$, show significant difference in May, August and December $\left(\mathrm{p}<0.05 ; \mathrm{NH}_{4}{ }^{+}-\mathrm{N}: \mathrm{p}=0.242\right)$. All water parameters, except $\mathrm{NH}_{4}{ }^{+}-\mathrm{N}$, show significant difference between control groups (no plants) and plant groups ( $\mathrm{p}<0.05 ; \mathrm{NH}_{4}{ }^{+}-$ $\mathrm{N}: \mathrm{p}=0.463$ ). However, to show the transforming of different forms of $\mathrm{N}$ in water, $\mathrm{NH}_{4}{ }^{+}-$ $\mathrm{N}$ concentration was still contained in Fig. 6.
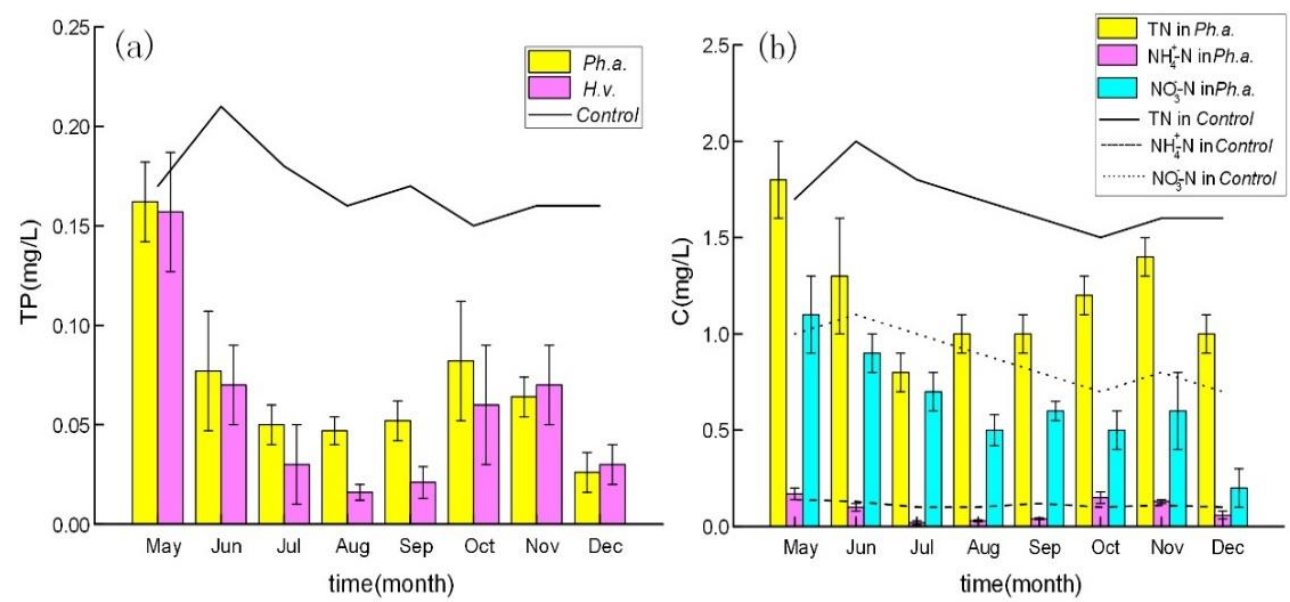

Figure 6. Changing trends of total phosphorus $(T P)(a)$ and three forms of nitrogen $(N)(b)$ in water samples with time. 'Ph.a.' and 'H.v.' represent water samples from Phragmites australis groups and Hydrilla verticillata groups, respectively. ' $\mathrm{TN}$ ', ' $\mathrm{NH}_{4}{ }^{+}-\mathrm{N}^{\prime}$ ' and ' $\mathrm{NO}_{3}{ }^{-} \mathrm{N}$ ' represent concentration of total nitrogen, ammonia nitrogen and nitrate nitrogen, respectively. In total 8 samples are collected for each month, of which 2 samples are collected every week. The mean values for each month are presented by color bars and the standard deviations are presented by error bars

\section{$p H, D O$ and $C O D$}

$\mathrm{pH}, \mathrm{DO}$ and COD in control groups show no signifcant difference with time ( $\mathrm{p}>0.05)$. Control groups $\mathrm{pH}$ was between 8.0 and 8.5 , water was alkalescence. DO fluctuated in 8.0-11.0 $\mathrm{mg} / \mathrm{L}$. COD was below $5.0 \mathrm{mg} / \mathrm{L}$ all the time and stayed at a relatively low level. 
In general, water quality of control groups is good (Table 1). Values of these 3 water parameters in aquatic plants are close and no significant difference is found $(\mathrm{p}>0.05) . \mathrm{pH}$ decreased from 8.0 to around 6.5 first, and then increased to 8.0, so the water changed from alkaline to faintly acidic and resumed to alkaline. It might have a relation with concentrations of phosphate radical $\left(\mathrm{PO}_{4}{ }^{3-}\right)$ and ammonium radical $\left(\mathrm{NH}_{4}{ }^{+}\right)$. DO kept low level in aquatic plant groups, the avarage was below $2.0 \mathrm{mg} / \mathrm{L}$. COD increased first then declined. These two parameters are both affected with plants biomass.

Table 1. $\mathrm{pH}$, dissolved oxygen (DO) and chemical oxygen demand (COD) in the water samples of aquatic plants and control groups

\begin{tabular}{c|ccc|ccc|ccc|ccc}
\hline \multirow{2}{*}{ Month } & \multicolumn{3}{|c|}{ Control } & \multicolumn{3}{c|}{ Ph.a. } & \multicolumn{3}{c|}{ Z.l. } & \multicolumn{3}{c}{ H.v. } \\
\cline { 2 - 12 } & pH & DO & COD & pH & DO & COD & pH & DO & COD & pH & DO & COD \\
\hline May & 8.5 & 7.7 & 2.7 & 8.1 & 3.8 & 5.6 & 8.0 & 4.0 & 6.5 & 7.3 & 2.7 & 6.3 \\
Jun & 8.3 & 8.0 & 2.6 & 7.7 & 3.3 & 9.9 & 7.8 & 3.3 & 9.6 & 7.5 & 1.3 & 13.6 \\
Jul & 8.1 & 8.2 & 2.8 & 7.5 & 2.5 & 13.7 & 7.5 & 2.1 & 13.4 & 7.3 & 0.5 & 19.4 \\
Aug & 8.2 & 8.4 & 2.5 & 7.6 & 2.0 & 15.8 & 7.2 & 1.0 & 15.0 & 7.3 & 0.3 & 23.3 \\
Sep & 8.5 & 8.7 & 2.3 & 7.2 & 0.8 & 11.9 & 7.3 & 1.3 & 10.6 & 7.1 & 0.1 & 16.0 \\
Oct & 8.3 & 8.7 & 2.6 & 6.7 & 1.2 & 9.0 & 6.6 & 0.7 & 8.5 & 6.5 & 0.2 & 12.7 \\
Nov & 8.0 & 8.5 & 2.7 & 6.9 & 1.4 & 7.3 & 7.0 & 0.9 & 6.8 & 7.1 & 0.3 & 9.5 \\
Dec & 8.2 & 8.0 & 2.5 & 7.6 & 2.0 & 6.0 & 7.4 & 1.4 & 5.5 & 7.7 & 0.5 & 6.6 \\
\hline
\end{tabular}

The unit of DO and COD are both $\mathrm{mg} / \mathrm{L}$. 'Ph.a.', 'Z.l.' and 'H.v.' represent water samples from Phragmites australis groups, Zizania latifolia groups and Hydrilla verticillata groups, respectively. In total 8 samples are collected for each month, of which 2 samples are collected every week

\section{$N \& P$ in water}

Values of TN\&TP in water have no significant difference in emerged plants (TN: $\mathrm{p}=0.534$; TP: $\mathrm{p}=0.730$ ). Also the changing trends are similar. Therefore, Ph.c. is selected as representative of emerged plants for plots (Fig. 6).

The TP in water of control groups ranged from $0.15 \mathrm{mg} / \mathrm{L}$ to $0.21 \mathrm{mg} / \mathrm{L}$, with a continuously declining trend. Range of $\mathrm{TN}\left(\mathrm{NO}_{3}{ }^{-} \mathrm{N}, \mathrm{NH}_{4}{ }^{+}-\mathrm{N}\right)$ in water of control groups was 1.5-2.0 mg/L (0.7-1.1 mg/L, 0.10-0.14 mg/L). TN and $\mathrm{NO}_{3}^{-}-\mathrm{N}$ both declined with fluctuations, while $\mathrm{NH}_{4}{ }^{+}-\mathrm{N}$ maintained a steady state with slight fluctuations. This reflects the process of nutrient exchange between water and sediment forced by concentration gradient. The TP in water of plant groups decreased at the beginning and near the end of the experiment. The range of $\mathrm{TN}\left(\mathrm{NO}_{3}{ }^{-}-\mathrm{N}, \mathrm{NH}_{4}{ }^{+}-\mathrm{N}\right)$ was $1.00-2.00 \mathrm{mg} / \mathrm{L}$ $(0.20-1.10 \mathrm{mg} / \mathrm{L}, 0.03-0.17 \mathrm{mg} / \mathrm{L})$, which were all lower than those in control groups (p<0.05). $\mathrm{NH}_{4}{ }^{+}-\mathrm{N}$ accounts for less than $10 \%$ of $\mathrm{TN}$ on average while $\mathrm{NO}_{3}{ }^{-}-\mathrm{N}$ accounts for more than $50 \%$ of $\mathrm{TN}$ on average.

Comparing control groups and plant groups, it can be concluded that plants can stimulate nutrient flowing, and biochemical action is a more powerful force than concentration gradient. $\mathrm{NO}_{3}{ }^{-} \mathrm{N}$ is the main form of $\mathrm{N}$ existing in water and transform between $\mathrm{NO}_{3}{ }^{-}-\mathrm{N}$ and $\mathrm{NH}_{4}{ }^{+}-\mathrm{N}$ are controlled by nitrification and denitrification (Reddy et al., 1990). From May to August TN\&TP in water of emerged plants decreased by 0.800 $\mathrm{mg} / \mathrm{L}$ and $0.115 \mathrm{mg} / \mathrm{L}$, respectively while those of submerged plants decreased by 1.000 $\mathrm{mg} / \mathrm{L}$ and $0.141 \mathrm{mg} / \mathrm{L}$, respectively. Declines of TN\&TP in water of submerged plants 
are greater than those of emerged plants $(\mathrm{p}<0.05)$. Submerged plants act better in removing N\&P loads than emerged plants.

\section{Correlation analysis}

The experiment lasted 8 months (May-December). Plants and sediment samples were collected twice per month (at 10th and 20th), while water samples were collected 4 times per month (including 10th and 20th). Besides, each experimental container had a duplicate (Fig. 2). Thus, parameters of samples at 10th and 20th every month are used for spearman correlation analysis, and the number of samples were 32.

Correlations of TN, TP in plants and sediment are shown in Table 2. There is a significant negative correlation between $\mathrm{TN}$ in roots of emergent plants and TN in sediment. TN in submerged plants has a significant negative correlation with $\mathrm{TN}$ in sediment. TP in plants and sediment does not present strong correlation. It indicates that $\mathrm{N}$ flow mainly occurred between plants and sediment directly by biochemical action of roots.

Table 2. Spearman's rank correlation coefficient of $N \& P$ between aquatic plants and sediments

\begin{tabular}{|c|c|c|c|c|c|c|}
\hline \multicolumn{7}{|c|}{ Ph.a. } \\
\hline \multirow{2}{*}{ Sediment } & \multicolumn{2}{|c|}{ Leaf } & \multicolumn{2}{|c|}{ Stem } & \multicolumn{2}{|c|}{ Root } \\
\hline & $\mathrm{TN}$ & $\mathrm{TP}$ & $\mathrm{TN}$ & TP & $\mathrm{TN}$ & TP \\
\hline $\mathrm{TN}$ & -0.692 & -0.167 & -0.095 & -0.079 & $-0.903^{* *}$ & -0.733 \\
\hline $\mathrm{TP}$ & -0.429 & -0.396 & -0.381 & -0.245 & -0.123 & -0.054 \\
\hline \multicolumn{7}{|c|}{ Z.l. } \\
\hline \multirow{2}{*}{ Sediment } & \multicolumn{2}{|c|}{ Leaf } & \multicolumn{2}{|c|}{ Stem } & \multicolumn{2}{|c|}{ Root } \\
\hline & $\mathrm{TN}$ & $\mathrm{TP}$ & $\mathrm{TN}$ & $\mathrm{TP}$ & $\mathrm{TN}$ & TP \\
\hline $\mathrm{TN}$ & -0.214 & -0.108 & -0.214 & -0.095 & $-0.819^{*}$ & -0.524 \\
\hline $\mathrm{TP}$ & -0.046 & -0.180 & -0.333 & -0.476 & -0.167 & 0.024 \\
\hline \multicolumn{7}{|c|}{ H.v. } \\
\hline Sediment & \multicolumn{3}{|c|}{ Plants TN } & \multicolumn{3}{|c|}{ Plants TP } \\
\hline $\mathrm{TN}$ & \multicolumn{3}{|c|}{$-0.833^{*}$} & \multicolumn{3}{|c|}{$-0.810^{*}$} \\
\hline $\mathrm{TP}$ & \multicolumn{3}{|c|}{0.381} & \multicolumn{3}{|c|}{0.286} \\
\hline
\end{tabular}

'Ph.a.', 'Z.l.' and 'H.v.' represent samples from Phragmites australis groups, Zizania latifolia groups and Hydrilla verticillata groups, respectively. TP and TN represent for total nitrogen concentration and total phosphorus concentration, respectively. $\mathrm{n}=32$ (number of samples). Statistical significance codes: $* \mathrm{p}<$ $0.05 ; * * \mathrm{p}<0.001$

Correlations of TN\&TP in plants and sediment with water parameters are shown in Table 3. There is no significant correlation in control groups. TN\&TP in emerged plant leaves and submerged plants have a strong positive correlation with water COD. There is a significant negative correlation between TP in water and sediment. These suggest plant growth may increase the content of organic matters in water, which can be a hazard of aquatic plants restoring eutrophicated lakes. P flow mainly relies on water since it shows no strong correlation between plants and sediments but presents a significant negative correlation between water and sediments. 
Table 3. Spearman's rank correlation coefficient of $N \& P$ in aquatic plants and sediment with water parameters

\begin{tabular}{|c|c|c|c|c|c|c|c|c|c|}
\hline & & & pH & DO & COD & $\mathbf{T P}$ & TN & $\mathrm{NH}_{4}{ }^{+}-\mathrm{N}$ & $\mathrm{NO}_{3}^{-}-\mathrm{N}$ \\
\hline \multirow{2}{*}{ Control } & \multirow{2}{*}{ Sediment } & $\mathrm{TN}$ & 0.000 & -0.185 & 0.354 & 0.536 & 0.607 & 0.350 & 0.590 \\
\hline & & $\mathrm{TP}$ & 0.068 & -0.202 & 0.110 & 0.647 & 0.479 & 0.595 & 0.513 \\
\hline \multirow{8}{*}{ Ph.a. } & \multirow{2}{*}{ Leaf } & $\mathrm{TN}$ & -0.060 & -0.072 & $0.922^{* *}$ & -0.180 & -0.552 & -0.627 & -0.078 \\
\hline & & $\mathrm{TP}$ & 0.683 & 0.683 & 0.19 & 0.452 & 0.268 & -0.060 & 0.659 \\
\hline & \multirow{2}{*}{ Stem } & $\mathrm{TN}$ & 0.587 & 0.635 & 0.119 & 0.524 & 0.220 & 0.012 & $0.755^{*}$ \\
\hline & & $\mathrm{TP}$ & 0.647 & $0.719^{*}$ & 0.167 & 0.476 & 0.220 & -0.024 & $0.719^{*}$ \\
\hline & \multirow{2}{*}{ Root } & $\mathrm{TN}$ & -0.647 & -0.623 & 0.024 & 0.429 & 0.415 & 0.335 & 0.096 \\
\hline & & TP & -0.373 & -0.133 & -0.455 & -0.310 & $0.761^{*}$ & 0.819 & 0.548 \\
\hline & \multirow{2}{*}{ Sediment } & $\mathrm{TN}$ & 0.371 & 0.347 & -0.476 & -0.333 & -0.073 & -0.120 & 0.048 \\
\hline & & $\mathrm{TP}$ & -0.323 & -0.204 & 0.190 & $-0.826^{*}$ & -0.537 & 0.012 & -0.671 \\
\hline \multirow{8}{*}{ Z.l. } & \multirow{2}{*}{ Leaf } & $\mathrm{TN}$ & -0.048 & -0.084 & $0.952^{* *}$ & -0.299 & 0.335 & -0.623 & 0.060 \\
\hline & & $\mathrm{TP}$ & 0.132 & 0.125 & $0.886^{* *}$ & -0.211 & 0.380 & -0.584 & 0.211 \\
\hline & \multirow{2}{*}{ Stem } & TN & 0.643 & 0.643 & 0.524 & 0.431 & 0.671 & -0.275 & $0.743^{*}$ \\
\hline & & $\mathrm{TP}$ & 0.643 & 0.594 & 0.357 & 0.491 & -0.695 & -0.060 & $0.719^{*}$ \\
\hline & \multirow{2}{*}{ Root } & $\mathrm{TN}$ & $-0.810^{*}$ & $-0.841^{*}$ & 0.333 & 0.024 & -0.144 & 0.275 & -0.144 \\
\hline & & $\mathrm{TP}$ & $-0.762^{*}$ & $-0.793^{*}$ & 0.310 & -0.048 & -0.395 & 0.108 & -0.180 \\
\hline & \multirow{2}{*}{ Sediment } & $\mathrm{TN}$ & 0.381 & 0.314 & -0.310 & -0.359 & -0.252 & -0.347 & -0.156 \\
\hline & & $\mathrm{TP}$ & -0.357 & -0.344 & 0.071 & $-0.874^{* *}$ & -0.371 & -0.515 & -0.554 \\
\hline \multirow{4}{*}{ H.v. } & \multirow{2}{*}{ Plant } & $\mathrm{TN}$ & -0.012 & -0.096 & $0.905^{* *}$ & -0.482 & 0.096 & -0.619 & -0.466 \\
\hline & & $\mathrm{TP}$ & -0.025 & -0.096 & $0.857^{* *}$ & -0.518 & 0.084 & -0.690 & -0.479 \\
\hline & \multirow{2}{*}{ Sediment } & $\mathrm{TN}$ & -0.074 & -0.036 & -0.619 & 0.265 & -0.252 & 0.429 & 0.184 \\
\hline & & $\mathrm{TP}$ & 0.356 & -0.024 & 0.548 & $-0.778^{*}$ & -0.299 & -0.690 & -0.675 \\
\hline
\end{tabular}

Explanation of abbrevations: Phragmites australis groups (Ph.a.), Zizania latifolia groups (Z.1.), and Hydrilla verticillata groups (H.v.), total nitrogen concentration (TN), total phosphorus concentration (TP), dissolved oxgen concentration (DO), ammonia nitrogen concentration $\left(\mathrm{NH}_{4}{ }^{+}-\mathrm{N}\right)$ and nitrate nitrogen concentration $\left(\mathrm{NO}_{3}{ }^{-} \mathrm{N}\right) . \mathrm{n}=32$ (number of samples). Statistical significance codes: $* \mathrm{p}<0.05$; $* * \mathrm{p}<0.001$

\section{Discussion}

\section{Difference of nitrogen and phosphorus flow}

The difference of N\&P flow is that $\mathrm{N}$ transfers mainly between sediments and plants, while $\mathrm{P}$ needs water to realize cycling. $\mathrm{P}$ in water is diversified into the total particle phosphorus (TPP) and the total dissolved phosphorus (TDP). Large amount of TPP can transfer in a short time. Most of $P$ release during the eluviation (Liu et al., 2018) is one phenomenon caused by this. It implies $\mathrm{P}$ flow is mainly a physical process. Biochemical actions of plants have minor effect on P flow (Smil, 2000). It can explain the strong correlation of $\mathrm{P}$ in sediment and water, also the conclusion of $\mathrm{P}$ flow relying on water. In addition, this conclusion applies to some natural catchments. For example, TPP is the main form of $\mathrm{P}$ in many rivers (Meybeck, 1982). $\mathrm{N}$ is identified as the organic nitrogen $(\mathrm{ON})$ and the inorganic nitrogen (IN). The latter is the main form of $\mathrm{N}$ in water and sediment. IN can be known as $\mathrm{NH}_{4}{ }^{+}-\mathrm{N}, \mathrm{NO}_{3}{ }^{-} \mathrm{N}$, and $\mathrm{NO}_{2}{ }^{-} \mathrm{N}$. But plants need to transform IN to $\mathrm{ON}$ to meet growing requirements. It indicates $\mathrm{N}$ flow is mainly through 
biochemical reaction, which is also concluded in other research (Rattray et al., 1991). For example, $\mathrm{NO}_{3}{ }^{-} \mathrm{N}$ can be transformed to $\mathrm{NH}_{4}{ }^{+}-\mathrm{N}$ through catalytic reduction by nitrate reductase (May et al., 2011); nitrification and denitrification, influenced by plants growth, can make mutual transformation of $\mathrm{NH}_{4}{ }^{+}-\mathrm{N}, \mathrm{NO}_{3}{ }^{-}-\mathrm{N}$, and $\mathrm{NO}_{2}^{-}-\mathrm{N}$ (Reddy et al., 1990). Thus there is a significant negative correlation between $\mathrm{N}$ in plant roots and sediment, and $\mathrm{N}$ flow is mainly between plants and sediment rather than between sediment and water.

\section{Emerged plants vs submerged plants}

Emerged plant leaves and stems are usually above water surface, while roots and part of stems are under water surface. Therefore, emerged plants have properties of both land and aquatic plants. Their roots are the main organ absorbing nutrient from sediments, meanwhile they can get abundant sunlight. Thus they usually show large biomass. Besides, emerged plants can weaken hydraulic dynamics and prevent sediment suspended (Hans, 1997). Furthermore, it can reduce sediments desorption effects. To sum up, emerged plants have significant effects on N\&P in sediment, which is also showed in the correlation analysis of this study. Submerged plants are usually entirely under water surface, so they have larger biomass within water than emerged plants. Large biomass is likely to make water turn to anaerobic state which will stimulate the release of N\&P (Reddy et al., 1990; Liu et al., 2002). In this study, sharp decrease of TN\&TP in H.v. during Aug.-Oct. (Fig. 4) verifies the conclusion mentioned above. The submerged plants have roots degraded due to the limitation of light intensity (Phillips et al., 1978; Jones et al., 1999), but their other parts all have the ability of absorbing water and nutrient. Thus submerged plants have strong connections with $\mathrm{N} \& \mathrm{P}$ in water. In natural lakes, commensalisms and competitions between emerged and submerged plants are ubiquitous, and it is worthy of consideration in further studies.

\section{Some suggestions for aquatic plants restoration}

According to Fig. 6, N\&P in water show a sharp decline during plants growth, which indicates aquatic plants do have the ability of removing excess nutrient in water. Moreover, submerged plants act better than emerged plants in removing nutrient, so submerged plants are the superior choice in restoring eutrophicated lakes. And some studies, focusing on effects of submerged plants restoration, have already verified the practicability of this suggestion (Gao et al., 2017). However, the results also show aquatic plants can release a large amount of N\&P when they decay. Therefore, it may cause a secondary pollution unless aquatic plants are reaped scientifically. For saving cost, it's essential to know the time and main plant organs to reap. Reaping the 3 aquatic plants around August and September is a proper timing. At this time around 70-75\% TP and $80 \%$ TN of water can be removed according to Fig. 6 . However, this value could be lower in lakes since hydrodynamics and some other conditions are not considered in this study. Besides, emerged plant leaves need to be reaped by times, since leaves fall easily in natural environment and the residue can release nutrient directly into sediment and water. Although emerged plant roots contain most nutrient when plants decay, it is not suggested to reap roots, because they are the key of plant regeneration and moderate residues are helpful to remove $\mathrm{N}$ (Gessner, 2000; Hernes et al., 2001). If controlling P loads is the main purpose, it is imperative to reap plants before $\mathrm{P}$ in plants reach the peak. The reason is the amount of P release is large within a short time when plants decay (Liu et al., 2018). 
On the other hand, if controlling $\mathrm{N}$ loads is the main purpose, reducing content of $\mathrm{NO}_{3}^{-}-$ $\mathrm{N}$ by enhancing denitrification would be an effective action.

In Fig. 6, there is another low value occurring around November and December, because N\&P are adsorbed by sediments after plants decay. Thus, purifying sediments at this time can remove around $90 \% \mathrm{~N} \& \mathrm{P}$ in water. Although this value could be lower in lakes where water and sediment interactions are strong, purifying sediment is still necessary to prevent sediment become the source of N\&P. However, it is too costly to initiate a project specifically for such purpose. As a result, the purification can be combined and included within some other engineering projects like dredging and reclamation at the appropriate time. As this experimental study has simplified some complicated environmental conditions, further studies could be done to find more integrated solutions for restoring the highly eutrophicated lakes.

\section{Conclusion}

For increasing the efficiency of using aquatic plants to restore eutrophic lakes and learning the rule of $\mathrm{N \& P}$ flow between water, aquatic plants and sediment, indoor experiments were conducted. The general process of N\&P flow in the system is from water and sediments to plants, then back to water, and finally they are adsorbed by sediments. However, $\mathrm{N}$ flow is mainly between plants and sediment, while $\mathrm{P}$ flow is mainly between water and sediment. Generally, $\mathrm{N}$ flow is a biochemical process, while $\mathrm{P}$ flow is a physical process. N\&P in emerged plants are stored in leaves at early and medium stages of growth (May-October) and transferred to roots at the decline stage (November-December). Submerged plants act better in removing excess nutrient in water, but harvesting them before $\mathrm{N} \& \mathrm{P}$ contents reaching peak is indispensable (August). Purifying sediments after plants decay (December) can be helpful to decrease N\&P loads, which can be combined and included within some other engineering projects.

Competition and promotion exist between different species of aquatic plants in nature, which may reduce or improve effects of using aquatic plants to restore eutrophic lakes. Thus, learning competition and promotion between different aquatic plants species is a meaningful direction for further study.

Acknowledgements. This work was partly supported by the National Key R\&D Program of China (2017YFC0405401), the National Natural Science Foundation of China (51620105005), the Jiangsu Science and Technology Program (SBK2015040816) and Jiangsu Water Conservancy Science and Technology Project (2016028). We would also like to thank Jiangsu Hydraulic Research Institution for providing equipment and place for the experiment.

\section{REFERENCES}

[1] American Public Health Association (1980): Standard Methods for the Examination of Water and Wastewater. - 15th edn. APHA, Washington, DC. 642 p.

[2] Bolpagni, R., Laini, A., Stanzani, C., Chiarucci, A. (2018): Aquatic Plant Diversity in Italy: Distribution, Drivers and Strategic Conservation Actions. - Frontiers in Plant Science 9: 112.

[3] Conley, D. J., Paerl, H. W., Howarth, R. W., Boesch, D. F., Seitzinger, S. P., Havens, K. E., Lancelot, C., Likens, G. E. (2009): Controlling eutrophication: nitrogen and phosphorus. Science 323(5917): 1014-1015. 
[4] Dodds, W. K. (2007): Trophic state, eutrophication and nutrient criteria in streams. - Trends in Ecology and Evolution 22(12): 669-676.

[5] Gao, H. L., Qian, X., Wu, H. F., Li, H. M., Pan, H., Han, C. M. (2017): Combined effects of submerged macrophytes and aquatic animals on the restoration of a eutrophic water body - A case study of Gonghu Bay, Lake Taihu. - Ecological Engineering 102: 15-23.

[6] Gessner, M. O. (2000): Breakdown and nutrient dynamics of submerged Phragmites shoots in the littoral zone of a temperate hardwater lake. - Aquatic Botany 66(1): 9-20.

[7] Guo, L. (2007): Doing battle with the green monster of Taihu Lake. - Science 317(5842): 1166.

[8] Hans, B. (1997): Do macrophytes play a role in constructed treatment wetlands. - Water Science \& Technology 35(5): 11-17.

[9] Hernes, P. J., Benner, R., Cowie, G. L., Goni, M. A., Bergamaschi, B. A., Hedges, J. I. (2001): Tannin diagenesis in mangrove leaves from a tropical estuary: a novel molecular approach. - Geochimica et Cosmochimica Acta 65(18): 3109-3122.

[10] Hilton, J., O'Hare, M., Bowes, M. J., Jones, J. I. (2006): How green is my river? A new paradigm of eutrophication in rivers. - Science of The Total Environment 365(1-3): 66-83.

[11] Jin, X., Tu, Q. (1990): The standard Methods for Observation and Analysis in Lake Eutrophication. - 2nd edition. Chinese Environmental Science Press, Beijing. (in Chinese).

[12] Jones, J. I., Young, J. O., Haynes, G. M., Moss, B., Eaton, J. W., Hardwick, K. J. (1999): Do submerged aquatic plants influence their periphyton to enhance the growth and reproduction of invertebrate mutualists. - Oecologia 120(3): 463-474.

[13] Liu, M., Hou, L. J., Xu, S. Y., Ou, D. N., Zhang, B. L., Liu, Q. M., Yang, Y. (2002): Characteristics of phosphate adsorption in tidal flat surface sediments of the Yangtze river estuary. - Acta Geographica Sinica 57(4): 397-406.

[14] Liu, S. L., Jiang, Z. J., Zhou, C. Y., Wu, Y. C., Arbi, I., Zhang, J. P., Huang, X. Q., Trevathan-Tackett, S. M. (2018): Leaching of dissolved organic matter from seagrass leaf litter and its biogeochemical implications. - Acta Oceanologica Sinica 37(8): 84-90.

[15] Magurran, A. E. (1988): Ecological Diversity And Its Measurement. - Springer, Croom Helm Ltd.

[16] May, S. K., Gu, L. J., Chen, H. M. (2011): The Role of Nitrate Reductase and Nitrite Reductase in Plant. - Current Biotechnology 3: 159-164.

[17] Meghdadi, A. (2018): Characterizing the capacity of hyporheic sediments to attenuate groundwater nitrate loads by adsorption. - Water Research 140: 364-376.

[18] Meybeck, M. (1982): Carbon, nitrogen, and phosphorus transport by world rivers. American Journal of Science 282(4): 401-450.

[19] Mo, S. Q., Zhang, X. F., Tang, Y. L., Liu, Z. W., Kettridge, N. (2017): Effects of snails, submerged plants and their coexistence on eutrophication in aquatic ecosystems. Knowledge \& Management of Aquatic Ecosystems 418: 44.

[20] O’Hare, M. T., Baattrup-Pedersen, A., Baumgarte, I., Freeman, A., Gunn, I. D. M., Lázár, A. N., Sinclair, R., Wade, A. J., Bowes, M. J. (2018): Responses of Aquatic Plants to Eutrophication in Rivers: A Revised Conceptual Model. - Frontiers in Plant Science 9: 451.

[21] Phillips, G. L., Eminson, D. Moss, B. (1978): A mechanism to account for macrophyte decline in progressively eutrophicated freshwaters. - Aquatic Botany 4: 103-126.

[22] Qiu, D. R., Wu, Z. B., Liu, B. Y., Deng, J. Q., Fu, G. P., He, F. (2001): The restoration of aquatic macrophytes for improving water quality in a hypertrophic shallow lake in Hubei Province, China. - Ecological Engineering 18(2): 147-156.

[23] Rattray, M. R., Howard-Williams, C., Brown, J. M. A. (1991): Sediment and water as sources of nitrogen and phosphorus for submerged rooted aquatic macrophytes. - Aquatic Botany 40(3): 225-237.

[24] Reddy, K. R., D'Angelo, E. M., Debusk, T. A. (1990): Oxygen Transport through Aquatic Macrophytes: The Role in Wastewater Treatment. - Journal of Environmental Quality 19(2): 261-267.

[25] Rooney, R. C., Bayley, S. E. (2011): Relative influence of local- and landscape-level habitat 
quality on aquatic plant diversity in shallow open-water wetlands in Alberta's boreal zone: direct and indirect effects. - Landscape Ecology 26(7): 1023-1034.

[26] Ruttenberg, K. C. (1992): Development of a sequential extraction method for different forms of phosphorus in marine sediments. - Limnology and Oceanography 37(7): 14601482.

[27] Smarta, M. M., Rada, R. G., Donnermeyer, G. N. (1983): Determination of total nitrigen in sediments and plants using persulfate digestion. An evalution and camparison with the Kjeldahl procedure. - Water Resource 17(9): 1207-1211.

[28] Smil, V. (2000): Phosphorus in the environment: Natural Flows and Human Interferences. - Annual Review of Energy and The Environment 25: 53-88.

[29] Tessier, J. T., Raynal, D. J. (2003): Use of Nitrogen to Phosphorus Ratios in Plant Tissue as an Indicator of Nutrient Limitation and Nitrogen Saturation. - Journal of Applied Ecology 40(3): 523-534.

[30] Valderrama, J. C. (1981): The simultaneous analysis of total nitrogen and total phosphorus in natural waters. - Marine Chemistry 10(2): 109-122.

[31] Wang, H., Edwards, M., Falkinham, J. O., Pruden, A. (2012): Molecular Survey of the Occurrence of Legionella spp., Mycobacterium spp., Pseudomonas aeruginosa, and Amoeba Hosts in Two Chloraminated Drinking Water Distribution Systems. - Applied and Environmental Microbiology 78(17): 6285-6294.

[32] Wang, J. B., Xu, J., Xia, J., Wu, F., Zhang, Y. J. (2018): A kinetic study of concurrent arsenic adsorption and phosphorus release during sediment resuspension. - Chemical Geology 495: 67-75.

[33] Wen, L., Recknagel, F. (2002): In situ removal of dissolved phosphorus in irrigation drainage water by planted floats: preliminary results from growth chamber experiment. Agriculture, Ecosystems and Environment 90(1): 9-15.

[34] Wu, X. D., Li, W. C., Pan, J. Z., Ma, S. Z., Chen, B. F., He, S. W. (2017): Restoration in northern Lake Gehu, a eutrophic lake in China. - Chinese Journal of Oceanology and Limnology 35(6): 1417-1431.

[35] Xiao, L., Yang, L. Y., Zhang, Y., Gu, Y. F., Jiang, L. J., Qin, B. Q. (2009): Solid state fermentation of aquatic macrophytes for crude protein extraction. - Ecological Engineering 35(11): 1668-1676.

[36] Xu, L. G., Pan, J. Z., Jiang, J. H., Zhao, H. B., Liu, C. H. (2013): A history evaluation modelling and forecastation of water quality in shallow lake. - Water and Environment Journal 27(4): 514-523.

[37] Zhang, Y. C., Ma, R. H., Zhang, M., Duan, H. T., Loiselle, S., Xu, J. D. (2015): FourteenYear Record (2000-2013) of the Spatial and Temporal Dynamics of Floating Algae Blooms in Lake Chaohu, Observed from Time Series of MODIS Images. - Remote Sensing 7(8): 10523-10542.

[38] Zhou, A. M., Tang, H. X., Wang, D. S. (2005): Phosphorus adsorption on natural sediments: Modeling and effects of $\mathrm{pH}$ and sediment composition. - Water Research 39(7): 1245-1254. 